\title{
PELAGIC FISH RESOURCE MANAGEMENT REGIME IN AMBON CITY FISHING GROUND BASED ON FISHERIES BIOECONOMICS
}

\author{
Matakupan Hansje \\ Fisheries Resource Utilization Study Program, Faculty of Fisheries and Marine Sciences, \\ University of Pattimura, Ambon, Indonesia \\ E-mail: jekysuymrs@gmail.com
}

\begin{abstract}
Fisheries resource management requires consideration of economic factors to increase benefits, without abandoning biological and fisheries factors, especially fishing technology. This study uses data and information on the potential, production, and level of utilization of pelagic fish resources by including fish prices and costs. The fisheries bioeconomics approach is used to determine the regime of pelagic fish resource management properly and appropriately. This study aims to analyze the value of bioeconomic parameters and the potential of pelagic fish resources in Ambon City and analyze the production, and the level of utilization of pelagic fish. Analysis of the potential of pelagic fish resources based on GordonSchaefer's bioeconomics, using multiple linear regression techniques with two control variables based on the equations of Shirakihara, (1994), Schnute (1977), and Uhler (1980). The development of production uses a modified periodic method (Dajan, 1983) and utilization level according to Sparre and Venema (1998). The results stated that the sustainable potential of pelagic fish resources in the management regime of MSY amounted to $178.942,68$ tons / year on fishing efforts $\left(f_{m s y}\right)$ of $4.634,62$ trips, and production could reach $89,471.34$ tons/year with economic rent equal to Rp. 114.224,34 million. The sustainable potential in the management regime of MEY amounted to192.627,73 tons/year on $f_{\text {mey }}$ equal to $4.280,17$ trips, and the production amounted to $44.648,12$ tons/year with economic rent equal to Rp. $218.841,42$ million. Actual production although fluctuating but tends to increase and in the last three years has increased significantly. The level of utilization of pelagic fish resources based on the management regime of MSY is $28,58 \%$ from MSY or $35,72 \%$ from JTB/TAC. The level of utilization based on the MEY management regime only reached $27,75 \%$ or $33.18 \%$ of JTB/TA.
\end{abstract}

\section{KEY WORDS}

Fishing ground, pelagic fish, Ambon city, fisheries, bioeconomics.

Pelagic fish resources is one of the natural resources that can be recovered, but it is a source of food that has a lot of demand because always consumed by local, national, and also exported to various countries. The high level exploitation of pelagic fish resources can cause this resource to diminish in fishing grounds, so that overfishing can occur at any time. Fishing ground is all the waters used by fishermen as a place (location) to operate a fishing gear. Prevention of overfishing in a fishing ground by gaining economic benefits through pelagic capture fisheries, can be done appropriately through fisheries bioeconomic analysis. According to Fauzi (2010), analysis of fisheries bioeconomics is needed to optimize benefits by combining biological, economic and fisheries science. This opinion suggests that the management of fisheries resources requires consideration of economic factors to increase benefits, without abandoning biological and fisheries factors, especially fishing technology. In order for all of these factors to be taken into account, then in the economic factors include the price of fish and costs used in the fisheries business unit.

Pelagic fishing business activities by Ambon City fishermen have long been carried out in the surrounding waters as a fishing ground, namely in the Inside Part of Ambon Bay, Outer Ambon Bay, South Ambon Island, and Seram Sea. Pelagic fishing technology that is applied by them by using boats and alat penangkap ikan pancing tangan (hand line), pancing tonda (troll line), pancing joran/"huhate" (pole and line), jaring angkat/"bagan" (lift net), jaring insang 
(gill net), pukat cincin/"jaring bobo" (purse seine), and pukat pantai/'jaring redi" (beach seine). The improvement of the pelagic fishing technology applied by Ambon City fishermen can be done properly and apropriately if the potential, production and utilization level/ rate of pelagic fish are known. Data and information on the production and utilization of fish resources through the capture fisheries sub-sector in Ambon city and various factors that influence it, can be used by fisheries researchers as reference material and/or comparison in conducting various fisheries research. Studies in the field of capture fisheries for the development of fisheries development in Ambon City by fisheries experts, can refer to the results of analysis of production and utilization of pelagic fish resources from Ambon City fishing ground.

The complexity of fisheries resources causes the need to develop a model that is needed as an approach in policy making, including using a bioeconomic approach. The combination of biology, economics and fisheries is known as fisheries bioeconomics. Bioeconomics of fisheries is a multi-disciplinary science. In bioeconomics, the basic model uses biological theories and concepts which are then combined with economic concepts. The use of economic concepts is intended to optimize the use of biological resources based on economic reviews. Whereas fisheries bioeconomics is the application of the bioeconomic concept in the fisheries sector.

The fisheries bioeconomic approach has not been used to determine the potential, fishing efforts, production, and value of benefits from the pelagic fish resources of Ambon City. The level of utilization and the amount of catchment allowed in pelagic fish resources from Ambon City fishing ground, at the present time has also not been analyzed and known. The fisheries bioeconomic approach is used to express it, so that the management of pelagic fish resources can be carried out properly and appropriately. The purpose of this study were (1) to analyze the value of bioeconomic parameters and the potential of pelagic fish resources in Ambon City, (2) analyze the production, and the level of utilization of pelagic fish based on fisheries bioeconomics. The results of this study can be a database and information that is used by all fisheries stakeholders as a management and utilization regime of pelagic fish resources in Ambon City and its surroundings, so that it is useful now and in the future.

\section{METHODS OF RESEARCH}

Data collection. This research was conducted in the Ambon City area, the administrative area of Ambon City and the surrounding waters. Collection of pelagic capture fisheries statistical data sourced from the Department of Marine and Fisheries, The Central Bureau of Statistics, and referenced with the results of data collection directly at the research site. Information and activities of fishing operations by Ambon City fishermen are obtained by the recording of the survey data using the method of Rapid Rural Appraisal (RRA) and Participation Rural Appraisal (PRA) (DKP, 2006; Freudenberger, 2008), equipped with closed or open questionnaires. This data and information was obtained from 170 (one hundred and seventy respondents in 16 (sixteen) research locations.

Data tables for survey needs are made in the form of certain matrices and formats, then recorded data are classified or tabulated according to the same type and character according to the research objectives. The survey results in the form of qualitative data are discussed descriptively and quantitative data is calculated in order to obtain the expected value in the discussion later. Data collection of other secondary information, as well as scientific reference sources, obtained from various current library sources that are published responsibly.

Analysis of bioeconomic, potential and production of pelagic fish resources parameters. Bioeconomic analysis of Ambon City's pelagic capture fisheries was carried out in order to predict biological, technological, and economic parameters. Bioeconomic parameters are thought to consist of biological, technological, and economic parameters. Biological parameters include the constant of waters carrying/ bearing capacity $(K)$, natural growth constants $(r)$, and technological parameters $(q)$. Economic parameters include the cost per 
fishing effort ( $c$ or $p)$, fish price per unit of catch $(p)$, and discount rate $(\delta)$. Estimation analysis of biological and technological parameters using multiple linear regression techniques with two control variables, applying several models (Clark, 1990; Seijo et al, 1998; Zulbainarni et al, 2002 in Najamuddin, 2013) namely:

$$
Y=\beta_{0}+\beta_{1} X_{1}+\beta_{2} X_{2}
$$

Some suggested models are as follows:

Model 1, Shirakihara (1994):

$$
\left(C P \cup E_{t+1}-C P U E_{t}\right) / C P \cup E_{t}=\beta_{0}+\beta_{1} C P \cup E_{t}+\beta_{2} E_{t}+e
$$

Model 2, Schnute (1977):

$$
\ln \left(C P U E_{t+1}-C P U E_{t}\right) / C P U E_{t}=\beta_{0}+\beta_{1}\left(C P U E_{t+1}+C P U E_{t}\right) / 2+\beta_{2}\left(E_{t+1}+E_{t}\right) / 2+e
$$

Model 3, Uhler (1980):

$$
\left(C P U E_{t+1}-C P U E_{t}\right) / C P U E_{t}=\beta_{0}+\beta_{1}\left(C P U E_{t+1}+C P U E_{t}\right) / 2+\beta_{2}\left(E_{t+1}+E_{t}\right) / 2+e
$$

Model 4, Uhler (1980):

$$
\operatorname{In}\left(C P \cup E_{t+1} / C P \cup E_{t}\right)=\beta_{0}+\beta_{1} C P \cup E_{t}+\beta_{2} E_{t}+e
$$

Where:

CPUE $E_{t+1}$ : CPUE at time $\mathrm{t}+1$;

$\mathrm{CPUE}_{t}$ : CPUE at time $\mathrm{t}$;

$E_{t+1}$ : Fishing effort at time $\mathrm{t}+1$;

$E_{t}$ : Fishing effort at time $t$;

$\beta_{0}$ : Intersep;

$\beta_{1}$ : CPUE Regression Coefficient;

$\beta_{2}$ : Fishing effort regression coefficient;

$e$ : Estimation error.

Model testing conducted to determine the accuracy of the model used. A significant model is used in subsequent bioeconomic calculations by referring to the results of the diversity analysis, namely the model with the highest " $F$ " value and the lowest "P" value. Regression coefficient $\left(\beta_{0}, \beta_{1}, \beta_{0}\right)$ used to estimate biological and technological parameters (indirect parameters or as technological indicators) of the bioeconomic models $r, K$, and $q$ with the equations (Shirakihara, 1994; Schnute, 1977; Uhler, 1980 in Najamuddin, 2013) as follows:

$$
r=\beta_{0} ; K=r /\left(q \beta_{1}\right) ; \text { and } q=\beta_{2}
$$

Where:

$r$ : The constant of natural growth rate of the fish;

$K$ : The Constant of environmental carrying/ bearing capacity (waters);

$q$ : The ability/capture coefficient of a fishing gear.

The economic parameters of the bioeconomic model are calculated using the arithmetic average formula, i.e.:

$$
c=\sum c_{i} / n_{1} \text { and } p=\sum p / n_{2}
$$

Where:

c: Average fishing operation costs per year;

$c_{i}$ : Fishing costs per fishing effort of respondent $-\mathrm{i}$; 
$p$ : Average catch per kg or ton;

$p_{i}$ : The average price for the season $-\mathrm{l}$;

$n_{1}$ : Number of respondents;

$n_{2}$ : Number of seasons (peak, normal, famine).

The parameter of the discount rate $(\delta)$ of resources and time, is a characteristic of the dynamics of the model. The discount rate is the natural logarithm of the real interest rate that applies to a particular year written with the equation (Clark, 1990 in Najamuddin, 2013; Fauzi, 2010) as follow:

$$
\delta=\ln (1+i)
$$

Where:

$i$ : The nominal investment interest rate is reduced by the inflation rate.

The assumptions of the bioeconomic model applied are as follows:

- Population is in equilibrium condition;

- In equilibrium condition, fishing mortality $(F)$ is proportional to the fishing effort $€$ wherein the fishing coefficient $(q)$ is a proportional constant, so that $F=q E$. Catch per unit effort (CPUE) is the relative abundance index of the population. CPUE $=Y / E=$ $q X ;$

- Stock is limited by the constant environment carrying/ bearing capacity (K);

- Stock will respond quickly to variations in the scale of effort used;

- Constant fishing mortality $(F)$;

- Prices and marginal costs/averages are constant and do not depend on the level of effort used;

- The total cost is proportional to the effort and the change in slope on the total cost curve will change the bioeconomic and MEY level data.

The output of the bioeconomic model includes the estimation of optimal biomass (stock) $(X)$, optimal catch (Y), and fishing efforts $(E)$. According to Fauzi (2010), the GordonSchaefer model was developed based on sustainable production wherein the growth curve is in a long-term equilibrium condition (long run equilibrium). According to Najamuddin (2013), the calculation of the potential of MSY, MEY, and open access use the equations:

$$
E_{m s y}=r / 2 q ; Y_{m s y}=K / 4 ; \text { and } X_{m s y}=K / 2
$$

Analysis of fishing effort $\left(E_{\text {mey }}\right)$, fish biomass (stock) $\left(X_{\text {mey }}\right)$, and catch yield/production $\left(Y_{\text {mey }}\right)$ at Maximum Economic Yield (MEY) condition, by using the formula:

$$
E_{\text {mey }}=r / 2 q(1-(c / p q K)) ; X_{\text {mey }}=K((c / 2 p q K)+0,5) ; \text { and } Y_{\text {mey }}=K r / 2(1-(c / p q K))((c / 2 p q K)-0,5)
$$

On the condition of pelagic fisheries resources that are free/open (open access) because they are common property, then fishing effort $\left(E_{\infty}\right)$ and catch yield/production $\left(Y_{\infty}\right)$ analyzed by using formulas:

$$
E_{\infty}=2 . E_{m e y}, \text { or } E_{\infty}=r / q(1-(c / p q K)) \text {, and } Y_{\infty}=K r(1-(c / p q K)(c / p q K)
$$

Fishermen only accept opportunity costs and resource economic rents or economic benefits not obtained. Economic rent of the resource (economic rent) is defined as the difference between total revenues from resource extraction to all expenses incurred to extract it. The level of effort in this position is the level of effort in the equilibrium condition that Gordon calls it as "bioeconomic equilibrium of open access fishery" or bioeconomic balance in open access conditions. The economic model developed by Gordon (1954) was based on the Schaefer model and introduced overfishing in open fisheries. Revenues derived from the fishing are function of total sustainable revenues (TSR $=$ Total Sustainable Revenue) and Total cost (TC = Total Cost), then the profit $/$ rents can be calculated using the formula of Fauzi (2010). 
According to Fauzi (2010), several assumptions were used to develop the GordonSchaefer model to facilitate the understanding. These assumptions among others:

- Price per unit output, $(\mathrm{Rp} / \mathrm{kg})$ assumed constant or the demand curve is assumed to be perfectly elastic;

- Cost per unit effort (c) considered constant;

- Single species of fish resources (single spesies);

- Market structure is competitive;

- Only fishing factors that taken into account (do not include postharvest factors, etc.).

Production and Level of Utilization of Pelagic Fish Resources. The ability of fish production calculated in accordance with the distribution of fishery statistical data on the number and type of fishing gear which is operated by the fishermen in the city of Ambon, in order to take into account the level of utilization of pelagic fish resources. Production developmenti $\left(P_{p}\right)$ of Small pelagic fish from 2005 to 2015 were calculated using a modified periodic method (Dajan, 1983), with a mathematical formula:

$$
P_{p}=\left\{\left(C_{n+1}-C_{n}\right) / C_{n}\right\} \times 100 \%
$$

Where:

$C_{n+1}$ : total production of pelagic fish from Ambon City in the year " $\mathrm{n}+1$ ";

$C_{n}$ : total production of pelagic fish commodities from Ambon City in the year $-\mathrm{n}$.

The level of utilization of pelagic fish resources available in the fishing ground of Ambon City is calculated based on the percentage (\%) of the calculation of annual fish production capacity (ton) per estimation yield of potential pelagic fish resources (MSY) according to API and fishing trips available in the Ambon City fishing ground. The level of utilization of pelagic fish in Ambon City and its surrounding waters was analyzed according to Sparre and Venema (1998) by using the mathematical model as follows:

$$
T P_{i}=\left(C_{i} / M S Y\right) \times 100 \% \text { and } / \text { or } T P_{i}=\left(C_{i} / J T B\right) \times 100 \%
$$

Where:

$T P_{i}$ : The level of utilization of small pelagic fish resources in Ambon City in the year $-i C_{i}$ : The catch yield (production) of pelagic fish in the year $-\mathrm{l}$;

$J T B_{i}$ : The number of pelagic fish catches allowed in the year $-\mathrm{l}$;

$(J T B=0,8 M S Y$ (Kepmen KP RI No: 47/KEPMEN-KP/2016)).

According to Kepmen KP RI No: 47/KEPMEN-KP/2016, if the utilization rate/ level is $<0,5(<50 \%)$ it is said moderate that is fishing effort can be added, if $0,5 \leq T P<1(50 \% \leq$ TP $<100 \%)$ it is said fully-exploited namely the fishing effort is maintained with a tight monitor, and $T P \geq 1$ ( $\geq 100 \%)$ it is said over-exploited fishing effort should be reduced.

\section{RESULTS AND DISCUSSION}

Bioeconomic Parameters and Potential of Pelagic Fish Resources in Ambon City. Pelagic fish resources used by Ambon City fishermen through fishing activities, consisting of large pelagic and small pelagic fishes. Fishing operations conducted on fishing grounds in Ambon City and its surrounding waters. The waters of Ambon City and its surroundings are included in the Banda Sea waters. Based on the results of the reference at the study site, several small pelagic fish species that were dominantly captured in this fishing ground/ daerah penangkapan ikan (DPI) by Ambon City fishermen, namely layang (Decapterus spp), selar (Selar spp), kembung (Rastrelliger spp), terbang (Cypsilurus spp), sardin (Sardinella spp), and puri (Stolephorus spp). The big pelagic fish that dominantly caught were cob/ tongkol (Auxis thazard; Euthynnus affinis), skipjack / cakalang (Katsuwonus pelamis), and tuna madidihang (Thunnus albacares).

Production data (tons) of pelagic fish and annual (trip) fishing efforts for Ambon pelagic fishing activities by 7 (seven) types of fishing equipment, are used for fisheries bioeconomic 
analysis. Summary results of the statistical analysis of the four multiple regression equation as a form of bio-economic models to test the significance of the model shown in Table 1.

Based on the model significance test, the selected multiple regression equation model is model 4 according to Uhler (1980) because it has the highest "F" value and the lowest "P" value, namely $Y=0,241-0,0259 X_{1}+0,000026 X_{2}$. P value equal to 0,263 stated that $26,3 \%$ CPUE and fishing efforts could not explain the model or model could be explained by CPUE and fishing efforts amounted to $73,7 \%$. Equation of model 4 is stated to be more significant (meaningful) to explain biological and technological parameters compared to the equation formed by other models. This equation states that the values of titik potong (intersept), $\beta_{0}=0,241$; CPUE regression coefficient, $\beta_{1}=0,0259$; and the regression coefficient of fishing effort, $\beta_{2}=0.000026$.

Table 1 - The results of significance test of biological and technological parameter models with multiple regression equation using two control variables

\begin{tabular}{|l|l|l|l|}
\hline Model & Equations Formed & F-Value & P-Value \\
\hline \hline 1. Shirakihara (1994 & $Y=0,45-0,0240 X_{1}+0,000056 X_{2}$ & 0.93 & 0,440 \\
2. Schnute (1977) & $Y=-0,50+0,0082 X_{1}+0,000034 X_{2}$ & 0.03 & 0,968 \\
3. Uhler (1980) & $Y=-0,28+0,0150 X_{1}+0,000039 X_{2}$ & 0.02 & 0,975 \\
4. Uhler (1980) & $Y=0,241-0,0259 X_{1}+0,000026 X_{2}$ & 1.63 & 0,263 \\
\hline
\end{tabular}

Source: Processed from the Maluku Province Marine and Fisheries Service (2006-20016) which was verified.

Calculation of the sustainability of pelagic fish resources with a bioeconomic model, requires the value of several parameters, namely biology, technology, and economics. Estimation of bioeconomic parameters as biological and technological indicators using the model 4 equation, so that it is known that the constants of natural growth rate of pelagic fish $(r)$ equal to 0,241 . This means that small pelagic fish will increase by 0,241 units from the potential of pelagic fish resources which available in the waters around Ambon City as fishing grounds. The constant of waters carrying/ bearing capacity $(K)$ is $357.885,36$ tons/year, stating that the potential of pelagic fish resources available in the waters of Ambon City and its surroundings as a fishing ground that can be utilized is $357.885,36$ tons/year. Catchability coefficient of pelagic fish $(q)$ amounted to 0,000026 , stating that one unit of pelagic fishing equipment operated by Ambon City fishermen, if accumulated, has an average of catchability (proportion) of 0,000026 units for each fishing effort (trip). The values of the biological, technological, and economic parameters of the pelagic capture fisheries in Ambon City, shown in Table 2.

The development of Gordon-Schaefer's model in the bioeconomics analysis of this pelagic capture fisheries resources, assumes price per unit output $(p)$ and cost per unit effort (c) considered constant. The price of pelagic fish in Ambon City varies throughout the year according to the type, size, fishing base, and fishing season, following the market mechanism. The price of pelagic fish used in bioeconomic analysis is based on the price of the types of pelagic fish that dominant caught throughout the year, then the average price is calculated per unit volume ( $\mathrm{kg}$ converted to tons). The pelagic fishing operation costs used in the analysis are the variable costs incurred in each trip of the fishing operation by each type of fishing gear. Costs incurred per trip of fishing operations to produce $1 \mathrm{~kg}$ of pelagic fish, then converted into variable costs per ton of pelagic fish catch yield. Components of variable costs recorded according to the fishing method, consist of fuel costs, consumption / supplies, ice, bait, fishermen's wages, FADs, and others. Resource discount rate/discount rate $(\delta)$ calculated based on the bank's real interest rate namely the difference between the percentage of average bank's nominal interest rate and the percentage of the average inflation rate in a year.

The values of biological ( $r$ and $K$ ), technological $(q)$, and economics $(p, c$, and $\delta)$ parameter, then used to analyze the utilization of pelagic fish resources in a sustainable manner with a bioeconomic approach. The results of the analysis of the value of biomass (tons), fishing effort (trip), production (tons), and profit / rent (Rp.) based on various systems of pelagic fish resource management can be seen in Table 3. 
Table 2 - The value of the biological, technological, and economic parameters of the pelagic capture fisheries in Ambon City

\begin{tabular}{|l|l|l|l|}
\hline No. & Parameter Symbol & Value & Information \\
\hline \hline 1. & $R$ & 0,241 & The constants of natural growth rate of pelagic fish \\
2. & $K$ & $357.885,36$ & $\begin{array}{l}\text { The constans of Environmental carrying/ bearing capacity } \\
\text { (tons/year) of waters }\end{array}$ \\
\hline 3. & $Q$ & 0,000026 & Catchability coefficient from pelagic fishing gear \\
\hdashline 4. & $P$ & 14.500 .000 & Average pelagic fish prices (Rp./Ton) \\
\hline 5. & $\Delta$ & 8,01 & Discount rate based on the bank's real interest (\%) \\
\hline 6. & $C$ & 10.318 .530 & Average pelagic fishing operation costs (Rp./Ton) \\
\hline
\end{tabular}

Source: Processed from the Maluku Province Marine and Fisheries Service (2006-20016) which was verified; Primary data (processed).

Table 3 - The parameter values of biomass, effort, production and rent based on Pelagic fish resource management system in Ambon City

\begin{tabular}{|c|c|c|c|c|c|}
\hline \multirow{2}{*}{ No. } & \multirow{2}{*}{ Information } & \multirow{2}{*}{ Parameter Symbol } & \multicolumn{3}{|c|}{ Pelagic Resource Management Regime } \\
\hline & & & MSY & MEY & Open Access \\
\hline 1. & "Biomass (Ton/Year) & $\bar{X}$ & $178.942,68$ & $192.627,73$ & $27.370,11$ \\
\hline 2. & Fishing effort (Trip) & $E$ & $4.634,62$ & $4.280,17$ & $8.560,35$ \\
\hline 3. & Production (Ton/Year) & Y & $89.471,34$ & $44.648,12$ & $3.045,87$ \\
\hline 4. & Rents (Million Rp.) & Л & $114.224,33$ & $218.841,42$ & 0,00 \\
\hline
\end{tabular}

Source: Processed from the Maluku Province Marine and Fisheries Service (2006-20016) which was verified; Primary data (processed)

The results of calculations using Gordon-Schaefer's bioeconomic approach state the potential of pelagic fish resources in the condition of Maximum Sustainable Yield (MSY) namely 178.942,68 tons/year bigger 12,13\% and in the condition of Maximum Economic Yield (MEY) namely 192.627,73 tons/year bigger 20,71\% from the potential of pelagic fish resources at the WPPNRI 714 (Banda Sea) according to Kepmen KP RI Number 47/Kepmen-KP/2016 that is equal to 159.578 tons/year. Data of Pelagic fish production and fishing efforts (trip) are sourced from fishing operations by Ambon City fishermen on fishing ground/ DPI which are only partially from the WPPNRI 714. This condition can explain that the prediction of the potential of pelagic fish resources in the Banda Sea fishing ground may be even greater. This is presumably due to the rapid growth of pelagic fish biomass due to the moratorium on fishing in part of WPP 714, and increasing / tightening supervision of the activities of IIlegal, Unreported and Unregulated (IUU) Fishing.

The optimal stock of pelagic fish biomass (stock) based on the management system in MSY conditions is smaller than the management system in MEY conditions, and is greater than the open access management system according to sustainable production functions. Fishing effort (trip) on pelagic fish resource management with MSY system is greater than MEY condition, but smaller than management system in open access condition. Production (tons) of pelagic fish is greater than the management system in open access conditions but smaller than the management system in MSY and MEY conditions. Fish production in the pelagic fish resource management system in the MSY condition amounted to 89.471.34 tons greater than fish production with a management system in MEY and open access conditions, but the economic profit / rent was Rp. 114.224,33 million smaller than the MEY management system which was Rp. 218.841,42 million according to a sustainable function management system. This fact is in accordance with what was stated by Fauzi (2010), that at point $E_{m s y}$ (MSY fishing effort) no maximum economic rents generated so that the input to the $E_{m s y}$ not said to be a socially optimal input. The MEY management system is an ideal management system for the sustainability of pelagic fish resources which results in greater economic rents with smaller fishing efforts. In Gordon-Schaefer's perspective, efficient and socially optimal management is at point $E_{\text {mey }}$ which is known as the maximum economic yield (MEY) balance/ equilibrium. This balance/ equilibrium point can be obtained if the fishery is controlled with a clear ownership regime or often termed the "sole owner" regime. 
Optimal fishing efforts with more than 8.560,35 trip open access management systems, but produce less pelagic fish production of $3.045,87$ tons compared to other management systems and do not get economic profit/rent. In this open access management system, stock of biomass of pelagic fish resources are also smaller than other management systems namely $27.370,11$ tons/year. The open access pelagic fisheries resource management system is very uneconomical because with larger fishing efforts, it only produces smaller fish production without obtaining economic benefits. The implementation of an open access management system will threaten the sustainability of pelagic fish resources so that it is not recommended to be allowed to occur.

The pelagic fish resource management system in maximum sustainable production conditions (MSY), economically allocates pelagic fish biomass stock equal to $178.942,68$ tons/year. Pelagic fishing efforts amounted to 4.634,62 tons/year produce $89.471,34$ tons/year of production and profit/rent equal to Rp. 114.224,33 million, through the MSY management system. Economically, a pelagic fisheries management system based on sustainable economic production (MEY) is better than other management systems. With a smaller fishing effort namely 4.280,17 trips/year, it can produce pelagic fish production of $44.648,12$ tons/year and profit/rent equal to Rp. 218.841,42 million. The profit/rent obtained is greater than the MSY and open access management system. Similarly, larger stocks of pelagic fish biomass (stock) namely 192.627,73 tons/year compared to other management systems. Gordon in Fauzi (2010) states that the balance/ equilibrium of open access is not socially optimal because the cost is too large.

Fishing efforts (trip) on the Maximum Sustainable Yield (MSY) management system and the Maximum Economic Yield (MEY) management system are far less than open access to achieve benefits in sustainable conditions or the sustainability of pelagic Fish Resources. The open access balance/ equilibrium leads to the misallocation of natural resources due to excess of production factors and should be allocated for other more productive economic activities. This is the core of Gordon's prediction that open access fisheries will create economic overfishing conditions. In the case of open access management of pelagic fish, fishermen tend to increase fishing and production efforts even though there are few biomass stock. Additional efforts were conducted by increasing fishing trips or fishing gear. This results in increased production so that the balance/ equilibrium of management will be achieved at the level of effort $\left(E^{2}\right)$, wherein total revenue equals total cost $(T R=T C)$. In this case, fisheries actors only receive opportunity costs and economic resource rents or economic benefits are not obtained. The level of effort in this position is the level of effort in the equilibrium condition that Gordon calls it as "bioeconomic equilibrium of open access fishery" or economic balance/ equilibrium in conditions of open access (Fauzi, 2010).

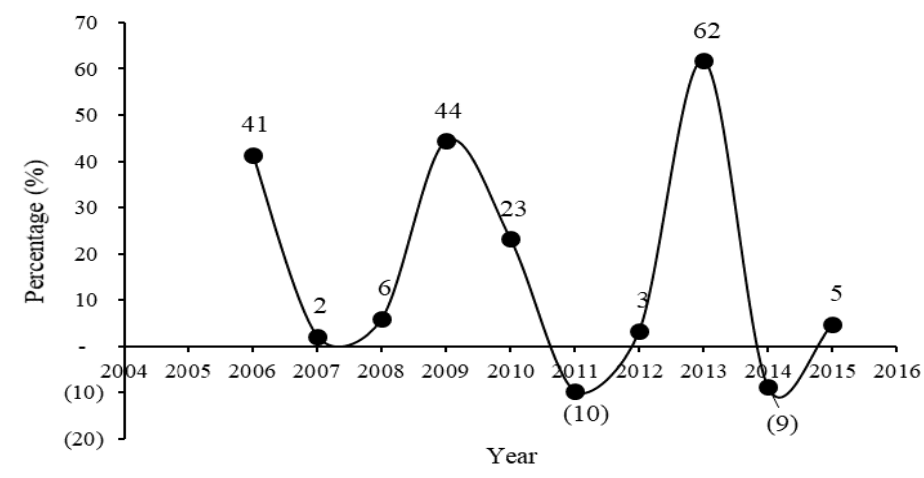

Figure 1 - Trajectory percentage (\%) of the development of pelagic fish production in Ambon City in 2005-2015

Production and Level of Utilization of Pelagic Fish Resources in Ambon City. Pelagic fish production from this fishing activity, shows dynamic fluctuations according to the time and location of fishing during 2005 to 2015, but tends to increase because the application of pelagic fishing technology by Ambon City fishermen has improved. Percentage (\%) of the 
fluctuating development of pelagic fish production for 11 (eleven) years, 3 (three) times down and 3 (three) times up. Pelagic fish production fell in 2006 to 2007, 2009 to 2011, and 2013 to 2014. Pelagic fish production increased in 2007 to 2009, in 2011 to 2013, and in 2014 to 2015, as shown in Figure 1.

The condition of the development of pelagic fish production when examined its suitability with the use of pelagic KPI and API by Ambon City fishermen, apparently in those years the pattern is not the same. Thus, the development of pelagic fish production is also influenced by other fishing technology factors besides KPI and API, for example the application of fishing methods, fishing season, fisherman skills, etc.

The estimation of the potential of Pelagic fish resources in Ambon City using GordonSchaefer's bioeconomic approach, obtained a higher/greater potential value (biomass) than the estimation using the Schaefer model. With this approach, the level of utilization of pelagic fish resources is analyzed based on the potential at the condition of Maximum Sustainable Yield (MSY) and Maximum Economic Yield (MEY) only. The management of pelagic fish resources in a state of optimal ideal balance (equilibrium), in reality is very difficult even impossible conducted (achieved) and in the case of open access, it is highly discouraged and difficult to find on the Fishing Ground, so that the two management systems are not used as reference.

The potential which is an index of relative abundance of pelagic fish in the Fishing Ground of Ambon City at the condition of Maximum Sustainable Yield (MSY), according to Gordon-Schaefer bioeconomic approach amounted to 178.943 tons. The potential of this pelagic fish is used as a reference for its management, by analyzing the condition of annual actual production so that it is known the utilization rate/ level that has been achieved, as shown in Figure 2.

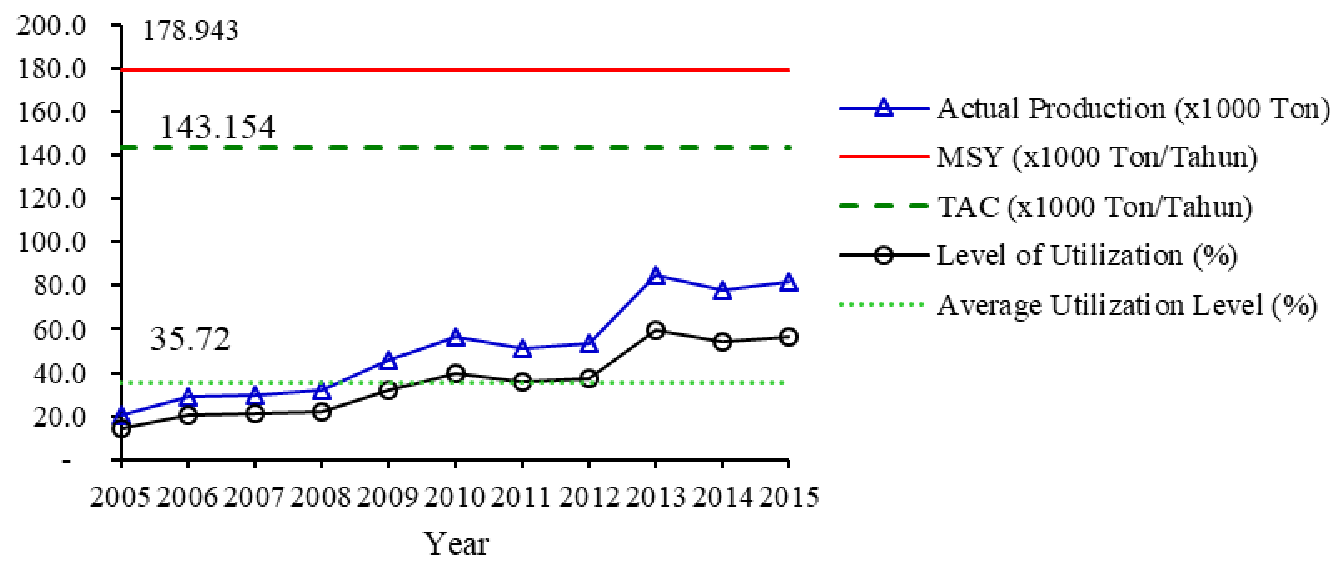

Figure 2 - The state/ condition of actual production and the level of utilization of pelagic fish at Ambon City in 2005-2015 towards MSY by bio-economic approach (Gordon-Schaefer)

Based on the increase annual actual production, then the rate/ level of utilization of Pelagic Fish Resources in the Fishing Ground of Ambon City from MSY Gordon-Schaefer also showed an improvement from 2005 to 2015. The level of utilization of pelagic fish resources in the city of Ambon is an average amounted to $28,58 \%$ from MSY or $35,72 \%$ from JTB/TAC in the pelagic resources management system which refers to MSY. Starting from 2010 , the utilization rate/ level of pelagic resources has been more than the annual average and continues to increase until 2015. Starting from 2010, the level in the last three years (2013 - 2015), the average utilization rate/ level of pelagic fish resources from Ambon City Fishing Ground was 45,49\% from MSY or 56,87\% from JTB/TAC, and the highest in 2013 amounted to 47,60 from MSY or $59,50 \%$ from JTB/TAC. This situation indicates the possibility to increase pelagic fish production from Ambon City Fishing Ground in order to achieve the total allowable catch (JTB/TAC) namely equal to 143.154 tons/year. 
The suggested pelagic fish resource management in Ambon City is by refer to sustainable maximum economic management system (Maximum Economic Yield/MEY). can be achieved at the MEY level namely equal to 192.628 tons / year. In Figure 3, shown the actual production conditions and utilization rates/ level of pelagic fish in Ambon City Fishing Ground towards the total allowable catch (JTB/TAC) and the level of utilization of pelagic Fish Resources.

The results of the analysis of the relative potential or abundance of pelagic Fish Resources in the form of biomass (stock) at the sustainable maximum economics level (maximum economic Yield/ MEY) amounted to 19.168 tons/year. Based on the actual production of pelagic fish resources from 2005 to 2015 by Ambon city fishermen, then the average of utilization rate/ level with the pelagic Fish Resource management system with reference to MEY has only reached $27,75 \%$ of $M E Y$ or $33.18 \%$ from JTB/TAC which amounted to 154.102 tons/year.

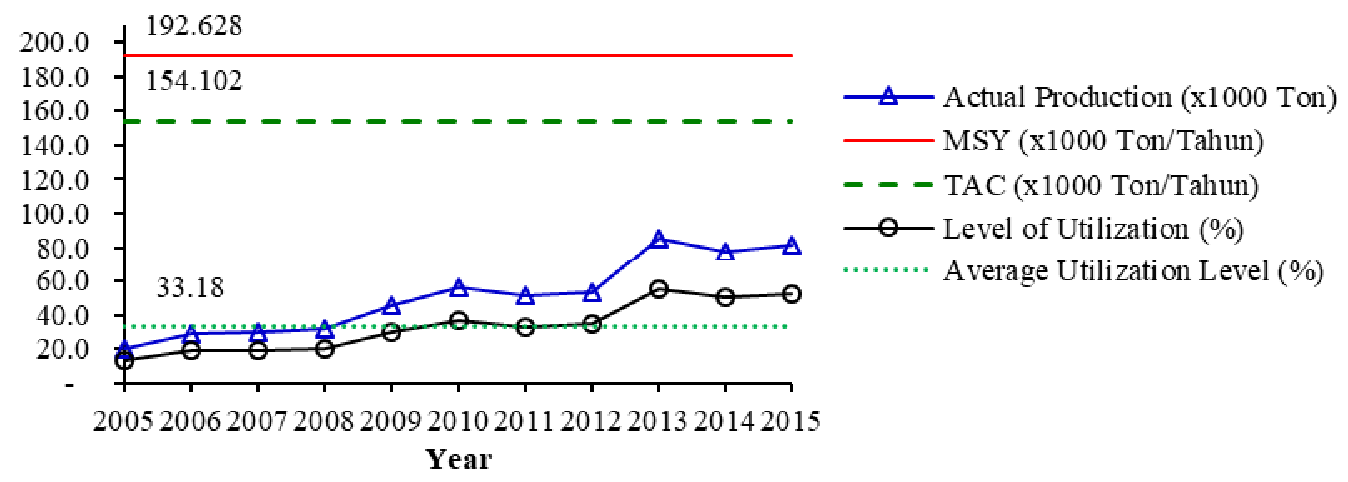

Figure 3 - The condition of actual production and the level of utilization of pelagic fish at Ambon City in 2005-2015 towards MEY with bio-economic approach (Gordon-Schaefer)

The above facts prove that the actual production of pelagic fish by Ambon City fishermen tends to increase from 2005 to 2015. The increase in production has occurred so far, but the utilization rate/ level in accordance with the management system of MEY is still small so that the production can be further increased. The production situation in the last three years fluctuated, which in 2013 tended to increase significantly, but tended to fall again in 2014 , then rose again in 2015 , with an average utilization rate/ level equal to $42,26 \%$ from MEY or $52,83 \%$ from JTB/TAC. This means that in the last three years, pelagic fish production in Ambon City has increased to reach a utilization rate/ level of more than half of JTB/TAC. This situation needs to be maintained, even production needs to be further improved by increasing fishing efforts (trips), increasing the number of pelagic API, improving $\mathrm{MPI}$, and revitalizing capture fisheries infrastructure.

\section{CONCLUSION}

This research concludes several things according to the purpose. as follows:

Biological parameter values in the form of the constants of natural growth rates of pelagic fish $(r)$ is 0,241 , technological parameters in the form of environmental carrying/ bearing capacity $(K)$ equal to $357.885,36$ tons/year and catchability coefficient from pelagic fishing gear $(q)$ is 0,000026 . The values of economic parameters in the form of pelagic fish prices $(p)$ an average of Rp. 14.500.000.- per ton, discount rate $(\delta)$ based on bank real interest amounted to $8,01 \%$, and the cost of pelagic fishing operations (c) an average of Rp. 10.318.530.- per ton. The sustainable potential of pelagic fish resources in the fishing ground in the management regime of Maximum Sustainable Yield (MSY) based on GordonSchaefer's bioeconomics is 178.942,68 tons/year on fishing efforts $\left(f_{m s y}\right)$ equal to $4.634,62$ trip, and production can reach 89.471,34 tons/year with economic rent of Rp. 114.224,34 million. The sustainable potential for the Maximum Economic Yield (MEY) management regime namely $192,627.73$ tons/year for fishing efforts $\left(f_{\text {mey }}\right)$ equal to $4.280,17$ trip, and 
production equal to $44.648,12$ tons/year with economic rent of Rp. $218.841,42$ million. It is recommended to manage fishing grounds based on the MEY management regime.

The actual production of pelagic fish in Ambon City is fluctuating, but tends to increase, even the average in the last three years has increased significantly. The average utilization rate/ level of pelagic fish resources from MSY was $28,58 \%$ from MSY or $35,72 \%$ from JTB/TAC and the highest in the last three years was $45,49 \%$ from MSY or $56,87 \%$ from JTB/TAC. The level of utilization of pelagic fish resources based on the MEY management regime has only reached $27,75 \%$ or $33,18 \%$ from JTB/TAC.

\section{SUGGESTIONS}

Data and information about the potential, production, and level of utilization of fish resources in Ambon City waters need to be known periodically so that the management does not deviate. Fish resource management regimes in fishing ground should be based on a fisheries bioeconomic approach so that could optimize the profit (benefits).

\section{ACKNOWLEDGMENTS}

The writer would like to thank the enumerators and brothers W. Waileruny as the Head of the Fisheries Resource Utilization Study Program, Faculty of Fisheries and Marine Sciences Pattimura University, which has joyfully helped to carry out this research.

\section{REFERENCES}

1. Badruddin, 2005. Analisis Data Catch \& Effort Untuk Pendugaan MSY. Fisheries Specialist, Indonesian Marine and Climate Support (IMACS) Project. USAID IndonesiaKKP.

2. Dajan A., 1983. Pengantar Metode Statistik Jilid I. Lembaga Penelitian, Pendidikan, and Penerangan Ekonomi and Sosial (LP3ES). Jakarta. (Edisi Revisi).

3. Departemen Kelautan and Perikanan, 2004. Ensiklopedi Perikanan. Direktorat Kelembagaan Internasional. Direktur Jenderal Peningkatan Kapasitas Kelembagaan and Pemasaran (Ditjen PK2P). Jakarta.

4. Departemen Kelautan and Perikanan, 2006. Panduan Pengambilan Data Dengan Metode Rapid Rural Appraisal (RRA) and Participatory Rural Appraisal (PRA). Program Rehabilitasi and Pemulihan Cadangan Sumberdaya Alam. Satker Rehabilitasi and Pengelolaan Terumbu Karang (COREMAP II) Tahun 2006. Dirjen KP3K. DKP. Jakarta.

5. Dinas Kelautan and Perikanan Provinsi Maluku. Buku Tahunan Statistik Perikanan Provinsi Maluku Tahun 2006 - 2016.

6. Freudenberger K. S., 2008. Rapid Rural Appraisal (RRA) and Participatory Rural Appraisal (PRA). A Manual for CRS Field Workers and Partners. 228 W. Lexinton Street. Baltimore. Maryland 21201-3443.

7. Gulland. J. A., 1991. Fish Stock Asessment. A Manual of Basic Methods. Marine Resources Service . Fishery Resources and Enviroment Division. FAO-UN. Rome. Italy. John Wiley and Sons.

8. Iswardono, 2001. Sekelumit Analisis Regresi and Korelasi. Fakultas Ekonomi UGM. Edisi Pertama. Cetakan Kelima. Dicetak and Diterbitkan oleh BPFE Yogyakarta. Yogyakarta.

9. Kawaguchi S., S. Nicol, K. Taki, and M. Naganobu, 2006. Fishing Ground Selection In The Antartic Krill Fishery: Trends in Patterns Across Years. Seasons and Nations. CCAMLR Science. Vol. 13 (2006). P 117-141.

10. Keputusan Menteri Kelautan and Perikanan Republik Indonesia Nomor 47/KEPMENKP/2016 Tentang Estimasi Potensi, Jumlah Tangkapan Yang Diperbolehkan, and Tingkat Pemanfaatan Sumberdaya Ikan Di Wilayah Pengelolaan Perikanan Negara Republik Indonesia.

11. King M., 1995. Fisheries Biology. Assesment and Management. Fishing News Book. A division of Blackwell Science Ltd. 
12. Nikijuluw V. P. H., 2002. Rezim Pengelolaan Sumberdaya Perikanan. Pusat Pemberdayaan Pembangunan Regional (P3R) dengan PT. Pustaka Cidesindo. Jakarta.

13. Nikijuluw V. P. H., N. V. Huliselan, Frits P. Lesnussa, and Hansje Matakupan, 2005. Analisis Sebaran Temporal Penangkapan Ikan Sebagai Basis Kebijakan Pengembangan Pelabuhan Perikanan Nusantara (PPN) Tual. Ichthyos. Jurnal Penelitian IImu-IImu Perikanan and Kelautan (Terakreditasi) Vol. 4 No. 2. Ambon.

14. Novita Lusi andriani and Dian Ayunita NDD, 2011. Potensi and Tingkat Pemanfaatan Sumberdaya Ikan Demersal di Perairan kabupaten Pekalongan. Jurnal UNDIP.

15. Peraturan Menteri Kelautan and Perikanan Republik Indonesia Nomor: 71/PERMENKP/2016 tentang Jalur Penangkapan Ikan and Penempatan Alat Penangkapan Ikan Di Wilayah Pengelolaan Perikanan Negara Republik Indonesia.

16. Sparre P., and S. C. Venema, 1998. Introduction to Tropical Fish Stock Assesment Part 1-Manual - FAO Fisheries Technical Paper. FAO Rome.

17. Steel R. G. D., and James H. Torrie, 1993. Prinsip and Prosedur Statistika. Suatu Pendekatan Biometrik. P.T. Gramedia Utama. Jakarta.

18. Undang-Undang Republik Indonesia Nomor 45 Tahun 2009 tentang Perubahan Atas Undang-Undang Nomor 31 Tahun 2004 tentang Perikanan.

19. Widodo J., 2001. Model-model Surplus Produksi Untuk Mengestimasi Hasil Tangkapan Maksimum Lestari (Maximum Sustainable Yield, MSY). Penuntun Pengkajian Stok Sumber Daya Ikan Perairan Indonesia. Proyek Riset and Eksplorasi Sumber Daya Laut, Pusat Riset Kelautan and Perikanan. DKP-Pusat Penelitian Oseanografi-LIPI. Jakarta

20. Widodo J., and Suadi, 2006. Pengelolaan Sumberdaya Perikanan Laut. Gadjah Mada University Press. P. O. Box 14. Bulaksumur. Yogyakarta 55281. 